๑ Entomologica Fennica. 26 October 1998

\title{
Boreal Olethreutini 1. (Lepidoptera: Tortricidae): New Synonymies and Holarctic Records
}

\author{
Jukka Jalava \& William E. Miller
}

Jalava, J. \& Miller, W. E. 1998: Boreal Olethreutini 1. (Lepidoptera, Tortricidae): New Synonymies and Holarctic Records. — Entomol. Fennica 9: 137-142.

We examined specimens of selected boreal palaearctic and nearctic taxa of Tortricidae to ascertain whether they might be holarctic conspecifics. Our findings confirm one putative synonymy: Tia enervana (Erschoff, 1877) = Argyroploce vulgana McDunnough, 1922, support four new synonymies: Olethreutes aquilonanus (Karvonen, 1932) = O. kononenkoi Kuznetsov, 1991, O. heinrichanus (McDunnough, 1927) = O. hyperboreanus (Karvonen, 1932), O. turfosanus (Herrich-Schäffer, 1851) $=$ O. intermistanus (Clemens, 1865), O. septentrionanus $($ Curtis, 1835) $=$ O. schaefferanus $($ Herrich-Schäffer, 1851) and resurrect one name from synonymy: the nearctic O. kennethanus McDunnough, 1941 is not conspecific with the palaearctic $O$. obsoletanus (Zetterstedt, 1840). Through synonymies and records, seven species are new for the Nearctic, and ten are considered holarctic. These results increase the percentage of holarctic Beringian tortricid species from 48 to 61 .

Jukka Jalava, Finnish Museum of Natural History, Zoological Museum, Division of Entomology, P. O. Box 17 (P. Rautatiekatu 13) FIN-00014 University of Helsinki, Finland

William E. Miller, Department of Entomology, University of Minnesota, 1980 Folwell Avenue, St. Paul, Minnesota 55108-6125, USA

Received 23 May 1997, accepted 20 April 1998

\section{Introduction}

Our collaboration started after Miller (1995) synonymized the Nearctic $E$. arctica Miller of Alaska and Yukon with the Transpalaearctic Epiblema simplonianum (Duponchel), thus making the latter holarctic. It seemed possible that other boreal, boreo-montane, and arcto-alpine tortricid taxa of Siberian Beringia and its Nearctic counterpart across the Straits might prove to be synonymous, holarctic, or both. We focused the investigation on species of Olethreutes and related genera of Olethreutini having northeastern Siberian distributions.

\section{Materials and methods}

Much of our material was collected by various Finnish-Russian expeditions to Siberia starting in 1982 (Kuznetsov \& Jalava 1988, Kuznetsov \& Mikkola 1991). Material was also collected during a Finnish expedition to Yukon in 1985, as well as during other Finnish collecting visits to Canada. Material in several North American museums was examined also. Some taxa discussed here are rare in museums, and the sexes of some have not yet been associated, hence the small numbers of specimens on which some conclusions are based. 
Nomenclature is reviewed only to the extent necessary for our purposes. For the most part, maculation among the species treated here is so similar as to be of little value in diagnosis. Unless otherwise noted, all specimens listed by sex $\left(0^{7}, \%\right)$ in Material Examined sections were dissected for genitalia study.

Depository abbreviations are as follows: ANSP, Academy of Natural Sciences, Philadelphia, Pennsylvania; CNC, Canadian National Collection, Ottawa; UCB, Essig Museum of Entomology, University of California, Berkeley; INHS, Illinois Natural History Survey, Champaign; UMEM, University of Minnesota Entomology Museum, St. Paul; USNM, U. S. National Museum of Natural History, Washington, D. C.; ZIN, Zoological Institute, St. Petersburg; MZH, Finnish Museum of Natural History, Helsinki.

\section{Results}

The following five species are holarctic by virtue of our confirming or proposing synonymies.

\section{Tia enervana (Erschoff)}

Penthina enervana (Erschoff 1877:341)

Argyroploce vulgana McDunnough (1922:46)

Kuznetsov (1987) reported Tia enervana to occur in northeastern Siberia and North America, and McDunnough (1922) described Argyroploce vulgana from Nordegg, Alberta, Canada. Our findings justify previous usage of the palaearctic senior synonym for Nearctic material (Kuznetsov 1987, Dang 1990), thereby confirming that the species is holarctic.

Material examined. RUSSIA: Kültuk, 19, 11.VI.[18]69 (enervana holotype) (ZIN); Polar Ural, 45 exx. (10' dissected), 6.-16.VII.94; Chukotka, 10', 3.VII.91 (MZH). CANADA: Nordegg, Alberta, 10', 11.VII.21 (vulgana holotype; previously published capture date corrected here), $1 \sigma^{\prime}$, 27.VI-14.VII.21 (vulgana paratype) (CNC); Aklavik, N.W.T., 107, 20.VII.31. USA: Peters Lk., Alaska, 10’, 14.VII.73; Schrader Lk., Alaska, 2\%, 4.-27.VII.73 (USNM); nr. Cantwell, Alaska, 20', 27.VI.-2.VII.79 (UCB).

\section{Olethreutes aquilonanus (Karvonen)}

Argyroploce aquilonana Karvonen (1932:77)

Olethreutes kononenkoi Kuznetsov, in Kuznetsov and Mikkola (1991:204). New Synonymy.

This species was long known only from northern Fennoscandia. In the Polar Ural of Russia, the moths were recently collected commonly on mountain tundra, which led to the recognition of the above synonymy. This synonymy makes the species transpalaearctic; we report it here as new for the nearctic, which makes it holarctic also.

Material examined. FINLAND: Malla, 107, 10.-18.VII.29 (aquilonanus holotype); Kilpisjärvi, 10", 9.VII.76; 19, 8.VII.43. RUSSIA: Kola Pns., 107, 18.VII.93; Polar Ural, 50", 19, 1.-15.VII.94; SW Altai, 19 exx., 20.-21.VII.83 (reported by Kuznetsov \& Jalava 1988 as $O$. aquilonanus helvomaculanus Kostjuk, a larger and brighter colored subspecies) (10 dissected in this study); Chukotka, Chukchi Pns., 10', 29.VII.82 (kononenkoi paratype). CANADA: Ogilvie Mts., Yukon, 20', 5.-6.VII.85 (MZH).

\section{Olethreutes heinrichanus (McDunnough)}

Argyroploce heinrichana McDunnough (1927:33)

Argyroploce hyperboreana Karvonen (1932:78) Lectotype designated here: Jenisej [Siberia], J. Sahlb., coll. Tengstr., Zool. Mus. H:fors, spec. type No. 7173 [male]; in MZH. New Synonymy.

As $O$. hyperboreanus, this species was reported to occur widely in the Palaearctic, including northeastern Siberia (Kuznetsov \& Mikkola 1991). As O. heinrichanus, it was previously known in the Nearctic only from Labrador (McDunnough 1927). The above synonymy makes the species holarctic, and the Alaska and Yukon records below suggest it being transnearctic as well.

Material examined. FINLAND: Lapland, several exx.; Li. Inari, 20', 6.VII.79. RUSSIA: Jenisej, $10^{\prime \prime}$ (hyperboreanus lectotype); Polar Ural, 10', 4.VII.94; Magadan, 10', 14.VII.87 (MZH). CANADA: "Ungava Bay, 76", 10 " (USNM); Yukon, 30', 4.VII.94 (MZH). USA: nr. Houston, Alaska, 10', 26.VI.79 (UCB).

\section{Olethreutes turfosanus (Herrich-Schäffer)}

Sericoris turfosana Herrich-Schäffer (1851:217) Mixodia intermistana Clemens (1865:140). New Synonymy. 
Heinrich (1926) considered the above two taxa to be distinct, citing different lengths of spined lower margins of the valvae. In our material, this difference is individual rather than taxonomic. As O. turfosanus, whose larvae probably live on Ericaceae and Vacciniaceae (Kuznetsov 1987), the species was reported to be transpalaearctic (Kuznetsov \& Mikkola 1991); the above synonymy makes it holarctic. Razowski (1983) photo-illustrated the wings and line-illustrated male and female genitalia (as Phiaris turfosana), and Heinrich (1926) photo-illustrated male and line-illustrated female genitalia of $O$. intermistanus.

Material examined. FINLAND: $>100$ exx. from throughout the country, the species being very common on peat bogs; Pellinge, 10", 19.VI.38. RUSSIA: Polar Ural, 25 exx., VII.94; SW Altai, 10 exx., 10.-14.VII.83 (30' dissected in this study); Irkutskaya obl., 16 exx., VII.84 (10 dissected in this study); Provideniya, Chukchi Pns., 10', 7.VII.91 (MZH). CANADA: Bilby, Alberta, 10', 23.VI.24; Churchill, Manitoba, 10', 5.VII.83; Hopedale, Labrador, 1\%, 24.VIII.31. USA: Mt. Katahdin, Maine, 10', 8.VII.39; Mt. Washington, N. H., 10', (no date) (USNM); nr. Anderson, Alaska, 10", 28.VI.79; nr. Cantwell, Alaska, 10", 1ㅇ, 27.VI.79 (UCB); Mt. Baker Natl. For., Wyoming, 2q, 1.VIII.36 (ANSP); Bangor, Maine, 19, 15.VI.38 (INHS).

\section{Olethreutes septentrionanus (Curtis)}

Orthotaenia septentrionana Curtis (1835:74)

Sericoris schaefferana Herrich-Schäffer (1851:211), New Synonymy.

Kuznetsov and Mikkola (1991) reported the palaearctic taxon from several areas including northeastern Siberia. The nearctic taxon was previously known only from Labrador (Heinrich 1926). The above synonymy makes the species holarctic. Razowski (1983) photo-illustrated the wings and line-illustrated the male and female genitalia (as Phiaris schaefferana), and Heinrich (1926) photoillustrated the male genitalia of $O$. septentrionanus.

Material examined. FINLAND: Lapland, where the species is locally common, many exx.; Malla, 10', 1.VII.36. RUSSIA: Kola Pns., many exx., 16.VII.91 (10 dissected in this study); Magadan obl., $80^{\circ}, 3$.VII.90 (10" dissected in this study) (MZH). CANADA: Labrador, 19, "609"; Bradore Bay, Quebec, 10", 14.VII.29 (USNM). USA: nr. Cantwell, Alaska, 10", 1ㅇ, 27.VI.79; nr. Anderson, Alaska, 10", 18.VI.79 (UCB).
The following five species are holarctic by virtue of our confirming or newly discovering their occurrence in the nearctic.

\section{Metendothenia atropunctana (Zetterstedt)}

\section{Penthina atro-punctana Zetterstedt (1840:977)}

Kuznetsov and Jalava (1988) reported this species to be transpalaearctic and possibly holarctic. Our findings confirm that it is indeed western nearctic and thus holarctic also, vicariated by $M$. separatana (Kearfott, 1907) in the eastern Nearctic. The maculation of these two species is similar, but the male genitalia, line-illustrated by Miller 1987 (as Hedya separatana), are different. The larvae of $M$. atropunctana feed in webbed leaves of species of Betula, Salix, Tilia, Fagus, and other genera (Bentinck \& Diakonoff 1968, Razowski 1983, Kuznetsov 1987). Bentinck and Diakonoff (1968) photo-illustrated the wings and genitalia of both sexes (as Hedya atropunctana), and Razowski (1983) photo-illustrated the wings and line-illustrated the genitalia of both sexes.

Material examined. FINLAND: Several exx. from throughout the country. RUSSIA: Kola Pns., 20, 1, 22.VI.93; Prov. Petropolis, $10^{7}$ (no date), Coll. Duske; CANADA: Ogilvie Mts., Yukon, 10', 12.VII.85 (MZH). USA: Dietrich River, Alaska, 10', 19.VII.1971 (UMEM).

\section{Olethreutes dalecarlianus (Guenée)}

\section{Selenodes dalecarliana (Guenée 1845: 160)}

Kuznetsov (1987) reported this species to be transpalaearctic; we report it here as new for $\mathrm{Ne}$ arctic, which thus makes it holarctic also. The larvae feed in tied leaves of species of Pyrola (Bentinck \& Diakonoff 1968, Razowski 1983, Kuznetsov 1987). Bentinck and Diakonoff (1968) photo-illustrated the wings and genitalia of both sexes (as Selenodes dalecarliana), and Razowski (1983) photo-illustrated the wings and line-illustrated the genitalia of both sexes (as Argyroploce dalecarliana). The maculation is very similar to that of the nearctic $O$. costimaculanus, which is discussed in another context further on, but these two taxa are distinct structurally. 
Material examined. FINLAND: Flaka, 4 exx., reared [19]48; Pernå, 19, 23.VI.42; Sortavala, 19, 29.VI.20; Karislojo, 1\%, "897"; Tervola, 10", 10.VII.71; Suojärvi, 10", 1939. RUSSIA: Magadan obl., 10', 15.-18.VII.87; Prov. Petropolis, (no date), 10', Coll. Duske. CANADA: Ogilvie Mts., Yukon, 10", 4.VII.85 (MZH). Wellington, British Columbia, "vi" (misidentified in 1925 as O. costimaculanus) (USNM).

\section{Olethreutes exaridanus Kuznetsov}

Olethreutes exaridanus Kuznetsov, in Kuznetsov and Mikkola (1991:202)

This species was previously known only from the Chukchi Peninsula type locality (Kuznetsov \& Mikkola 1991). We report it here as new for the nearctic, which thus makes it holarctic also.

Material examined. RUSSIA: nr. Provideniya, Chukchi Pns., 20', 9.-14.VII.91; Anadyr River, Chukchi Pns., 5ㅇ (paratypes, not dissected), 10', 21.VII.89. CANADA: Ogilvie Mts., Yukon, 10̛, 7.VII.85 (MZH).

\section{Olethreutes concretanus (Wocke)}

Penthina concretana Wocke (1862:57)

This boreal species, described from N-Norway, whose larvae are said to feed on Ericaceae and Vacciniaceae, was previously reported to be transpalaearctic (Kuznetsov 1987, Kuznetsov \& Mikkola 1991). We report it here as new for the nearctic, which thus makes it holarctic also. Kuznetsov (1987) line-illustrated the male genitalia.

Material examined. FINLAND: Middle parts of the country north to Lapland, 27 exx.. RUSSIA: Kola Pns., 13 exx.; Polar Ural, 2\%, 1.-6.VII.94; Upper Kolyma River, Magadan obl., 10", 19, 8.-18.VII.87; Chukchi Pns., 19, 7.VII.91 (MZH). USA: Eagle Summit, Alaska, 10', 2.VII.79; nr. Fairbanks, Alaska, 1, 1.VII.79 (UCB).

\section{Olethreutes palustranus (Lienig \& Zeller)}

Sericoris palustrana Lienig \& Zeller (1846:230)

This species was previously reported to be transpalaearctic (Kuznetsov and Mikkola 1991). We report it here as new for the nearctic, which thus makes it holarctic also. The larvae feed inside tubes constructed of moss stems (Bentinck \& Diakonoff 1968, Kuznetsov 1987). Bentinck and Diakonoff (1968) photo-illustrated the wings and genitalia of both sexes (as Argyroploce palustrana), and Razowski (1983) photo-illustrated the wings and line-illustrated the genitalia of both sexes (as Phiaris palustrana).

Material examined. FINLAND: Ca. 100 exx. from throughout the country (MZH); Nurmijärvi, 10', 7.VIII.71; Pellinge, 10', 20.VII.36; N. Esbo, 10', 21.VIII.65; Helsinki, 1\%, 10.VII.21 (UMEM). RUSSIA: SW Altai, 10', 9-14.VII.83 (MZH). USA: Galbraith Lk., Alaska, 10', 9.VII.79 (UCB); Schrader Lk., Alaska, 50', 1\%, 3.-26.VII.73 (USNM).

Based on our studies, the species discussed below, although Beringian, do not appear thus far to be holarctic.

\section{Olethreutes kennethanus McDunnough, New Status.}

Olethreutes kennethana McDunnough (1941:99)

Olethreutes obsoletana (not Zetterstedt 1840:980); Miller (1985:414)

We resurrect the name $O$. kennethanus because the taxon differs from $O$. obsoletanus in number, size, and arrangement of cornuti. In $O$. (or Phiaris) obsoletanus, there are three groups of cornuti: one group of one to three long ones at the tip of the aedeagus, and two separate vesical plates each with six or more short ones (Razowski 1983, Kuznetsov 1987). In O. kennethanus, there are up to five separate vesical cornuti, all long, and no plates of short cornuti. Also the sacculus differs: in O. kennethanus it is evenly curved and with rows of numerous spines; in $O$. obsoletanus it is more angulate and contains only a group of spines (Kuznetsov 1987). Staining of earlier genital preparations obscured the plates of short cornuti in $O . o b$ soletanus and thus led to the synonymical error.

Material examined. O. kennethanus: CANADA: Edmonton, Alberta, 10', 1.VIII.40 (holotype) (CNC); Churchill, Manitoba, 10', 4.VII.37 (USNM); Lk. Abitibi, Ontario, 10", 28.VII.92 (MZH). USA: Bear Creek, Alaska, 10", 28.VI.70; Mt. McKinley, Alaska, 10', 3.VII.38; Peters Lk., Alaska, 107, 1ㅇ, 14.VII.73 (USNM); nr. Cantwell, Alaska, 20', 27.VI.79(UCB). O. obsoletanus: FINLAND: Lapland, where the species is one of the most abundant lepidopterans, many exx. (80 dissected for this study); Kilpisjärvi, 10', 11.VII.34. RUSSIA: Polar Ural, 36 exx., 7.-13.VII.94 (20" dissected in this study); SW Altai, 70', 22.-27.VI.83 (10' dissected in this study); Irkutskaya obl., 10", 16-18.VII.84 (MZH). 


\section{Olethreutes mengelanus (Fernald)}

Sericoris mengelana Fernald (1894:131)

This nearctic species was previously known only from Greenland and Southampton Island, N. W. T. (Heinrich 1926, 1935). The new records below from Alaska and Yukon suggest a transnearctic distribution.

Material examined. GREENLAND: 10', 26.VI.21; 10", (no date); 1ㅇ, “29.7” (USNM). CANADA: Ogilvie Mts., Yukon, 10', 5.-6.VII.85 (MZH). USA: Barter Is., Alaska, 10', 25.VI.71 (UMEM).

Besides being Beringian and apparently confined to the Nearctic, the following three species have similar but distinct counterparts on the palaearctic side of the Straits. These pairs of species are examples of zoogeographic vicariants in the sense of Kuznetsov and Mikkola (1991).

\section{Olethreutes costimaculanus (Fernald)}

Penthina costimaculana Fernald (1882:70)

Besides superficially resembling the transpalaearctic $O$. dalecarlianus, as discussed earlier, the nearctic $O$. costimaculanus is also similar to O. ledianus (L.), another transpalaearctic species (Kuznetsov \& Mikkola 1991). We confirmed that the latter two taxa differ structurally, most notably by $O$. costimaculanus male genitalia having large, broad and blunt socii (small, narrow and sharp-tipped in $O$. ledianus). In female genitalia the papillae anales are several times larger than those of $O$. ledianus, as can be seen in published illustrations (Heinrich 1926, Bentinck \& Diakonoff 1968, Razowski 1983). Olethreutes costimaculanus was previously known to occur no further west in the nearctic than Alberta (Heinrich 1926), but the Yukon record below suggests it is transnearctic.

Material examined. O. costimaculanus: USA: Orono, Maine, 1\%, VI.17.[18]81 (lectotype) (USNM); Bangor, Maine, 29, VI.15.38 (INHS). CANADA: Meach Lk, Quebec, 10', 25.V.03; Mer Bleue, Ontario, 1ㅇ, (no date) (USNM); Ogilvie Mts., Yukon, 10", 4.VII.85; Newfoundland, $10^{7} 1949$ (MZH). O. ledianus: FINLAND: Many exx. from throughout the country, where the species is common on peat bogs. RUSSIA: Magadan obl., 1ㅇ, 30", 2.VII.90; Kola Pns., 10', 3.VII.93, 19, 2.VII.90 (MZH).

\section{Olethreutes bowmananus (McDunnough)}

Argyroploce bowmanana McDunnough (1923:165)

Although the line-illustration of the valva of this species (McDunnough 1923) is similar to that of O. exaridanus Kuznetsov (Kuznetsov \& Mikkola 1991), specimen comparisons showed that the uncus and socii are much smaller in $O$. bowmananus.

Material examined. O. bowmananus: CANADA: Nordegg, Alberta, 10', 7.VIII.23 (paratype); Banff, Alberta, 10', 4.VII.25; Moraine Lk., Alberta, 10', 7.VIII.23 (USNM); Ogilvie Mts., Yukon, 30', 3.-19.VII.85 (MZH). O. exaridanus: as enumerated in a previous discussion.

\section{Olethreutes minaki McDunnough}

Argyroploce minaki McDunnough (1929:270)

Although the line-illustration of the valva (McDunnough 1929) is similar to that of $O$. dissolutanus (Stange) (Kuznetsov 1987), specimen comparisons showed that the uncus differs in outline and the cornuti are much longer in $O$. minaki. Olethreutes dissolutanus, whose larvae live between tied moss-stems (Kuznetsov 1987), is distributed widely in the palaearctic, including northeastern Siberia (Kuznetsov \& Mikkola 1991).

Material examined. O. minaki: CANADA: Minaki, Ontario, 10", 8.VII.28 (paratype) (USNM). O. dissolutanus: FINLAND: Many exx., the species being moderately common in spruce forests. RUSSIA: SW Altai, 9 exx. (10 dissected), 23.-25.VII.83; Upper Kolyma River, Magadan obl., 12 exx. (20" dissected), 14.-28.VII.87 (MZH).

\section{Discussion}

The holarctic taxa discussed here are also Beringian. The number of Beringian tortricid species that are also holarctic previously stood at $48 \%$ (Miller 1995). With the net addition or confirmation here of 10 more holarctic species, the figure rises to $61 \%(42 / 69)$. We suspect this percentage will increase even more with further collecting and identification of unsorted nearctic and palaearctic material from Beringia.

Acknowledgement. We thank D. Azuma, R. L. Brown, P. J. Clausen, P. T. Dang, R. W. Hodges, V. I. Kuznetsov, K. Methven, and J. A. Powell for the loan of specimens in 
their care, and R. L. Brown and J. A. Powell for reviewing the manuscript. Special thanks to all the participants of the expeditions and to the Academy of Finland and Russian Academy of Sciences for granting and to J. Kullberg and L. Kaila for using their e-mail.

\section{References}

Bentinck, G. A. \& Diakonoff, A. 1968: De nederlandse Bladrollers (Tortricidae). - Monogr. Nederl. Entomol. Ver. 3, 200 pp.

Clemens, B. 1865: North American micro-lepidoptera. Proc. Entomol. Soc. Philadelphia 5: 133-147.

Curtis, J. 1835: Insects - In: Ross, J. C. (ed.), Appendix to the narrative of a second voyage in search of a northwest passage, and of a residence in the arctic regions during the years $1829,1830,1831,1832,1833$. London, A. W. Webster, pp. lix-lxxx. [Pagination not continuous.]

Dang, P. T. 1990: Redefinition of tribe Bactrini Falkovitsh and revised status of genera Taniva Heinrich and Hulda Heinrich (Tortricidae: Olethreutinae). - J. Lepid. Soc. 44: 77-87.

Erschoff, N. 1877: Diagnosen neuer Lepidopteren aus den verschiedenen Provinzen des Russichen Reiches. Horae Soc. Entomol. Ross. 12: 336-348.

Fernald, C. H. 1882: Descriptions of new species of Tortricidae. - Trans. Amer. Entomol. Soc. 10: 65-72.

Femald, C. H. 1894: North Greenland microlepidoptera. - Entomol. News 5: 129-132.

Guenée, M. A. 1845. Essai sur une nouvelle classification des microlépidoptères et catalogue des espèces européennes connues jusqu'à ce jour. - Ann. Soc. Entomol. France (ser. 2) 3: 105-192, 297-344.

Heinrich, C. 1926: Revision of the North American moths of the subfamilies Laspeyresiinae and Olethreutinae. - U. S. Natl. Mus. Bull. 132, 207 pp.

Heinrich, C. 1935: Heterocera. - In: Sutton, G. M. (ed), The exploration of Southampton Island, Hudson Bay. Pt. 2, Zoology. Sec. 5, Insects (Lepidoptera) and invertebrates. - Mem. Carnegie Mus. 12, pp. 27-29.

Herrich-Schäffer, G. A. W. [1849] 1851: Systematische Bearbeitung der Schmetterlinge von Europa. Vol. 4, Die
Zünsler und Wickler. - Manz, Regensburg, 218 pp.

Karvonen, V. J. 1932: Vier neue Kleinschmetterlinge aus Finnland. - Not. Entomol. 12: 77-81.

Kuznetsov, V. I. 1987: Family Tortricidae (tortricid moths). - In: Medvedev, G. S. (ed.), Keys to the insects of the European part of the USSR [translation]. - U.S. Dept. Agr. \& Natl. Sci. Found, pp. 279-956.

Kuznetsov, V. I. \& Jalava, J. 1988: Soviet-Finnish entomological expeditions to southern Siberia 1982-1984. 2. Tortricidae (Lepidoptera). — Nota Lepid. 11: 126-138.

Kuznetsov, V. I. \& Mikkola, K. 1991: The leaf-roller fauna of north-eastern Siberia, USSR, with descriptions of three new species (Lepidoptera, Tortricidae). - Nota Lepid. 14: 194-219.

Lienig, F. \& Zeller, P. C. 1846: Lepidopterologische Fauna von Lievland und Curland. - Isis 1846: 175-302.

McDunnough, J. 1922: Undescribed Lepidoptera in the Canadian National Collection. - Can. Entomol. 54: 34-47.

McDunnough, J. 1923: New Canadian Lepidoptera. - Can. Entomol. 55: 163-168.

McDunnough, J. 1927: Two new Canadian tortricids (Lepid.). - Can. Entomol. 49: 33-34.

McDunnough, J. 1929: Some apparently new microlepidoptera. - Can. Entomol. 61:266-271.

McDunnough, J. 1941: A new Albertan olethreutid. - Can. Entomol. 73: 98-99.

Miller, W. E. 1985. Nearctic Olethrentes: Five new synonymies, two revised statuses, and notes (Lepidoptera: Tortricidae). - Proc. Entomol. Soc. Washington 87: 408417.

Miller, W. E. 1987: Guide to the Olethreutine Moths of Midland North America (Tortricidae). - U.S. Department of Agriculture, Forest Service, Agriculture Handbook 660,104 pp.

Miller, W. E. 1995: Beringian Tortricidae: A new synonymy in Epiblema and a recount of holarctic species. - J. Lepid. Soc. 49: 250-252.

Razowski, J. 1983: Motyle (Lepidoptera) Polski, 6 - Olethreutinae: Olethreutidii. — Monogr. Fauny Polski 13, 177 pp.

Wocke, M. F. 1862: Reise nach Finnmarken II. Microlepidoptera, — Stett. Entomol. Zeit. 23: 30-78, 233-257.

Zetterstedt, J. H. 1840: Insecta lapponica. - L. Voss, Leipzig, $1139 \mathrm{pp}$. 